\title{
Neonatal hematology: a historical overview
}

\author{
Howard A. Pearson, M.D. \\ University School of Medicine, Yale New Haven Hospital, New Haven, CT, USA
}

Ancient concepts of the blood were described by Hippocrates and Galen 2000 years ago in their doctrine of "humors." It was believed that the body was made up of four humors - blood, phlegm, black bile, and yellow bile - and that these four components had the qualities of heat ("hot-blooded!"), cold, moist, and dry. The Galenic concept of the blood prevailed through the Middle Ages. Health or disease was a result of a balance or imbalance, respectively, between these humors, and this was the basis of the practice of therapeutic blood-letting (which, fortunately, was performed infrequently in children) through the mid nineteenth century as a way to rid the body of the abnormal humors believed to cause a wide variety of diseases.

The hematology of the fetus and newborn is a relatively recent area of study whose development depended upon the evolution of the science of hematology and, especially, upon methods to study the blood and its elements. As Wintrobe has pointed out, the development of the field of hematology has been driven by technology. He divided the evolution of hematology into two general areas: morphology, which relied on the development of microscopy, and quantitation of the elements of the blood, which came later [1].

The invention of the microscope enabled identification of the blood cells. Antonj van Leeuwenhoek, working in Delft, Holland, constructed a primitive microscope from a minute biconcave lens mounted between two metal plates attached to a screw that permitted focussing. Leeuwenhoek's publication in
1674 contained the first accurate description of the red blood corpuscles [2]:

The blood is composed of exceedingly small particles, named globules, which in most animals are red in color ... These particles are so minute that 100 of them placed side by side would not equal the diameter of a common grain of sand.

In the centuries following, the development of compound microscopes with two lenses greatly increased magnification and minimized spherical aberration, permitting more accurate descriptions of the blood cells. William Hewson, who has been designated as one of the "fathers of hematology," noted that the red cells were flat rather than globular and also described the leukocytes for the first time [3]. The last of the formed elements of the blood, the platelet, was recognized independently by several investigators. The most definitive early work on the platelet was done by Julius Bizzozero. His monograph, published in 1882, clearly recognized these cells as being distinct from red and white blood cells, and suggested that they should be called "Plättchen." He also assigned a hemostatic function to the platelet [4]. William Osler, early in his illustrious career, also described platelets accurately, although he believed that they might be infectious agents, perhaps analogous to bacteria [5].

With improvements in microscopy, the morphology of the fixed blood cells began to be examined using thin films of blood, spread and dried on glass slides, which were then stained with analine dyes that stained differentially the nuclei and granules of 
the leukocytes. Staining of peripheral blood smears was developed by Paul Ehrlich in 1877, while he was still a medical student, and became practical in the early twentieth century by the work of James Homer Wright of Boston, who formulated the polychromatic Wright stain that is still used today for morphologic examination of the blood and bone marrow [6]. The development of supravital dyes provided a method for assessment of erythropoiesis by reticulocyte counts. These techniques permitted the flowering of morphologic hematology, and many blood diseases such as the leukemias and the various types of anemia were described on the basis of typical morphological findings.

Hematology as a quantitative discipline began with the development of practical and reliable methods to quantify accurately the numbers of the various blood cells. These methods used gridded chambers of uniform depth (hematocytometers) into which precisely diluted suspensions of blood were placed. The numbers of cells in the chamber were counted and, when combined with the known dilutions, the actual numbers of cells per cubic milliliter in the patient's blood could be calculated. Hemoglobin levels were estimated by comparing the density of color in fixed dilutions of hemolyzed blood with colorometric standards and, later, by spectroscopy. For many years, hemoglobin values were reported as “\% of normal;" because the definition of "normal" was often different, however, there was considerable variability from study to study. In 1929, Maxwell Wintrobe described his method for obtaining the hematocrit or packed red-cell volume (PCV) by centrifugation of blood in a glass tube [7]. He then defined so-called red-cell indices, the mean corpuscular volume (MCV), mean corpuscular hemoglobin (MCH), and mean corpuscular hemoglobin concentration (MCHC), which proved of enormous value in classifying the various forms of anemia [8]. The latest advance in blood-cell quantitation began in the 1950s with the introduction of increasingly more complicated and sophisticated computer-driven electronic instruments that measure very accurately hemoglobin, the numbers of all the blood cells, as well as the red-cell indices and the red cell distribution width (RDW). Some instruments now also provide automated differential counts of the leukocytes.

Most of the pre-twentieth century American pediatric textbooks gave scant attention to hematologic problems of the neonate. Dewees's 1825 A Treatise on the Physical and Medical Treatment of Children, arguably the first American pediatric textbook, and Job Lewis Smith's 1869 A Treatise on the Diseases of Infancy and Childhood gave only passing notice to blood conditions of the neonate, such as neonatal jaundice and hemorrhage from improper ligature of the umbilical cord [9, 10]. However, the monumental text of L. Emmett Holt, The Diseases of Infancy and Childhood, first published in 1897, contained a section on "the Diseases of the NewlyBorn," including the hemorrhagic disease, and a 17page section on "the Diseases of the Blood," which included the normal blood findings in the newborn [11]. Holt was obviously familiar with the many studies published in the German literature, and his descriptions are reasonably consistent with modern findings:

The percentage of haemoglobin is highest in the blood of the newly born ... At this time the number of red blood corpuscles is from 4,350,000 to 6,500,000 in each cubic millimeter ... In size, a much greater variation is seen in the red cells of the neonate. In the blood of the foetus there are present nucleated red corpuscles or erythroblasts. These diminish in number toward the end of pregnancy. These are always found in the blood of prematures, but in infants born at term, they are seen only in small numbers. The number of leukocytes in the blood of the newly born is three or four times that of the adult, being on the average 18,000 per cubic millimetre.

In 1921, W. P. Lucas and associates from the University of California Medical School in San Francisco described their extensive studies of the blood of 150 infants at birth and during the first two months of life [12]. Their samples were obtained from serial punctures of the longitudinal sinus! The polycythemia of the newborn and changes in the leukocytes were defined clearly.

In 1924, H.S. Lippman from the University of Minnesota published detailed studies of the blood 
of newborn infants [13]. He noted (without further details) that "Denis published the first observations on the subject in 1831." Lippman's review of the literature cited 70 previous articles on the hematology of the newborn. Most of these studies were published in European, especially German, journals. Although there was considerable variability because of different methods and standards, the consensus of these early studies was that "hemoglobin values at birth are higher than at any other period in the child's life." Some of these studies described reticulocytosis and normoblastemia in the first day of life, which declined rapidly in the first week of life. Lippman conducted serial studies of capillary blood over the first 48 hours of life in 71 normal newborns as well as changes in the leukocytes during this period.

It has been known for 100 years that the red blood cells of the fetus and newborn are large compared with those of adults, as determined by microscopic measurement of red-cell diameter. Newer electronic cell-sizing techniques have demonstrated that the mean MCV of the neonate's red blood cells averages $110 \mathrm{fl}$, compared with the $90 \mathrm{fl}$ of adults. The red cells of midgestational fetuses are even larger [14].

In 1856, Korber, in an inaugural dissertation, is reported to have described his experiments that showed that solutions of the hemoglobin of newborn infants resisted denaturation by strong alkaline solutions and maintained a red color, while hemoglobin solutions from adults treated in the same way were rapidly denatured and decolorized [15]. The property of alkali resistance became the basis of the Singer one-minute alkali denaturation test for quantitation of fetal hemoglobin ( $\mathrm{Hb} \mathrm{F}$ ), as well as the Apt test, used to differentiate fetal from swallowed maternal blood in infants with gross blood in the gastrointestinal tract $[16,17]$. Fetal hemoglobin is also resistant to acid denaturation, which is the basis for the redcell acid elution staining procedure of Kleihauer and Betke that is used widely to quantitate the magnitude of fetomaternal transfusions [18].

The understanding of the protein structure of hemoglobin advanced rapidly in the 1950s when it was shown that adult hemoglobin, $\mathrm{Hb} \mathrm{A},\left(\alpha_{2} \beta_{2}\right)$ is a tetramer of alpha $(\alpha)$ and beta $(\beta)$ polypeptide chains and that $\mathrm{Hb} F\left(\alpha_{2} \gamma_{2}\right)$ contains a different pair of polypeptide chains designated as gamma $(\gamma)$ chains $[19,20]$. During fetal development, synthesis of $\gamma$ chains predominates, but with approaching term there is a fall-off of $\gamma$-chain synthesis and a simultaneous reciprocal increase in $\beta$-chain synthesis. The regulatory mechanisms that govern this " $\beta / \gamma$ switch" remain to be elucidated. The blood of the newborn contains large amounts of $\mathrm{Hb} \mathrm{F}$, averaging $60-80 \%$. The affinity of $\mathrm{Hb} \mathrm{F}$ for oxygen is greater than that of $\mathrm{Hb} \mathrm{A}$, because of poor binding of 2-3-diphosphoglycerate. This results in a shift of the oxygen dissociation curve to the left, which is favorable for oxygen transport to the fetus in the relative hypoxia of intrauterine existence but which may be disadvantageous after birth [21]. The high level of $\mathrm{Hb} \mathrm{F}$ at birth offers temporary protection from hemoglobinopathies such as sickle cell anemia and may hamper their diagnosis in the newborn. Roland Scott, using the classical "sickle cell prep," demonstrated a much lower frequency of "sicklemia" in black newborns than was found in older children from the same community [22]. The development of techniques such as acid agar gel electrophoresis has permitted genotypic diagnosis of most hemoglobinopathies at birth, and neonatal testing for hemoglobinopathies is now performed routinely in 47 states of the USA [23].

The only somewhat common hemoglobinopathy that produces symptoms in the newborn is homozygous $\alpha$-thalassemia resulting from deletion of four $\alpha$-globin genes [24]. In parts of Southeast Asia, fetal hydrops is caused much more frequently by $\alpha$-thalassemia than by Rh immunization. The recent immigrations of large numbers of Southeastern Asian people into the USA have resulted in increasing numbers of affected infants. Some of these have survived after intrauterine transfusions but are transfusion-dependent [25].

Since the turn of the twentieth century, a large number of studies of the hematology and blood diseases of the newborn have been reported. Much of this information has been incorporated into textbooks of hematology. Maxwell Wintrobe's 
monumental Clinical Hematology, which was first published in 1943, contained sections on normal blood values, anemias, and hemorrhagic disease of the newborn. Neonatal thrombocytopenia in infants born of mothers with ITP was also mentioned briefly. In subsequent editions of Wintrobe's text, many more neonatal hematological conditions were described. In 1960, Carl Smith published Blood Diseases of Infancy and Childhood, the first American textbook of pediatric hematology/oncology, which had several chapters devoted to normal values and hematologic problems in the neonatal period.

In 1966, Frank Oski and Laurie Naiman published the first textbook devoted solely to the hematology and hematological problems of the newborn [26]. The authors' stated purpose was

... to provide in a single source much of what is known concerning both the abnormal and abnormal hematologic processes of the first month of life and the effects of prenatal factors on them ... And to provide a useful guide to all who care for the newborn infant - those who are continually confronted with infants who are bleeding, anemic or jaundiced.

The Oski-Naiman text had two subsequent reeditions in 1972 and 1982. Subsequently, there have been a plethora of texts and handbooks on pediatric hematology, most of which devote chapters to the newborn.

The history of neonatal hematology and the process of understanding hematologic diseases based on clinical and laboratory observations that stimulate investigation of basic mechanisms and then therapeutic interventions are illustrated well by two quintessential neonatal blood diseases: erythroblastosis fetalis and hemorrhagic disease of the newborn.

\section{Erythroblastosis fetalis}

As recently as 1946, erythroblastosis fetalis, or hemolytic disease of the newborn, affected between $0.5 \%$ and $1.0 \%$ of fetuses and newborns in the USA. It had a $50 \%$ mortality as well as significant neurologic morbidity in many survivors [27]. Prior to 1936, four seemingly distinct neonatal syndromes had been identified: fetal hydrops; fetal erythroblastosis with massive red-cell proliferation in fetal organs; icterus gravis familiaris, a severe neonatal jaundice that often affected subsequent infants; and severe anemia in surviving infants who had not had edema or striking jaundice, which was simply called anemia of the newborn. Based on histological and hematological similarities and the familial occurrence, Diamond, Blackfan, and Baty put forth their unifying hypothesis that these four syndromes were all manifestations of an unknown single underlying disease process. They designated all of these neonatal syndromes "erythroblastosis fetalis" [28].

In 1938, Ruth Darrow, a pathologist, several children of whom had died of erythroblastosis, advanced a brilliant inductive hypothesis about its cause. Assembling all of the available information, as well as drawing on her personal experience, she noted the usual sparing of the first child and the involvement of most subsequently born children. She also recognized that the hematologic and histopathologic findings in these infants could be best explained by severe hemolysis. She concluded that the disease resulted because:

the mother is actively immunized against fetal red cells or some component of them ... The antibodies formed in the maternal organism may then pass to the child through the placenta [29].

The elusive offending antibody and its red-cell antigen were discovered in 1940 by Karl Landsteiner and Alexander Weiner. It was given the name Rh (rhesus factor) because the antibody was produced by injection of red blood cells of rhesus monkeys into rabbits. This antibody agglutinated the red cells of $85 \%$ of normal individuals [30]. Interestingly, Landsteiner's discovery of the Rh blood group was accomplished almost 50 years after he had discovered the ABO blood groups [31]. Philip Levine described a transfusion reaction in a postpartum woman who was given a transfusion of her husband's blood shortly after delivering a stillborn baby with hydrops fetalis. Levine was able to demonstrate $\mathrm{Rh}$ antibodies in the mother's circulation, defining clearly the pathophysiology of erythroblastosis fetalis $[32,33]$. 
Effective treatment for erythroblastosis fetalis progressed slowly. The treatment of icterus gravis by "exsanguination transfusion" was first reported in 1925 by A. P. Hart at Toronto's Hospital for Sick Children [34]. With the discovery of the Rh factor, exchange transfusion evolved rapidly as a way to remove circulating antibody, sensitized red blood cells, and bilirubin. This treatment was spearheaded by Harry Wallerstein and Alexander Weiner in New York and Louis K. Diamond in Boston. Wallerstein's method involved aspiration of blood from the sagittal sinus and infusion of Rh negative blood into a peripheral vein [35]. Weiner's method employed heparinization and surgical cannulation of the radial artery and saphenous vein. Interestingly, at a time long before institutional review boards for research, he first evaluated the technique in a nonerythroblastotic "mongolian idiot" [36]. Diamond's much more practical method utilized the umbilical vein to alternately remove and infuse blood, and this rapidly became the accepted method around the world [37]. Diamond developed practical guidelines for the prenatal and postnatal management of Rhsensitized mothers and their erythroblastotic newborns. These reduced neonatal mortality from $50 \%$ to $5 \%$ and intrauterine death from $20 \%$ to less than $10 \%$, and kernicterus associated with severe hyperbilirubinemia was virtually eliminated [38].

Implicit in the pathogenesis of Rh erythroblastosis is that small numbers of fetal erythrocytes gain entrance into the maternal circulation, where they evoke maternal immunization and Rh antibody formation. The possibility of large fetomaternal transfusion was first hypothesized by Weiner and later proven definitively by Bruce Chown, who used differential agglutination to demonstrate fetal red cells in the maternal circulation in a case of neonatal anemia [39, 40]. It is now recognized that acute, massive fetomaternal transfusion results in neonatal pallor and hypovolemic shock resembling asphyxia pallida, while chronic hemorrhage may be associated with well-compensated congenital microcytic hypochromic anemia due to iron deficiency [41].

The penultimate important developments in erythroblastosis fetalis were provided by A.W.
Liley of New Zealand, who devised a method of spectroscopic analysis of amniotic fluid. This identified immunized fetuses at high risk of intrauterine death and who could be given intrauterine intraperitoneal blood transfusion to carry them to delivery [42, 43]. Development of percutaneous umbilical blood sampling under ultrasonographic guidance has enabled perinatologists to directly diagnose and assess the severity of anemia in immunized fetuses and to treat them with simple or exchange transfusions in utero. Finally, Clark in Liverpool and Freda and associates in New York showed independently that primary isoimmunization of Rh-negative mothers by the Rh-positive red cells of their fetuses could be largely prevented by immediate postnatal administration of potent anti-Rh gamma globulin to the mother $[44,45]$. In most of the developed world, erythroblastosis fetalis has become a rare disease of largely historical interest, and exchange transfusions have become a lost skill.

\section{Hemorrhagic disease of the newborn}

Newborn infants may bleed seriously from several causes. More than 2000 years ago, the familial occurrence of severe bleeding following ritual circumcision of boys, who doubtless had hemophilia, was recognized:

It has been reported of four sisters at Sapphoris; the first one circumcised her son, and he died; the second, and he died; the third, and he died. Then the fourth came before Rabban Simeon be Ganalied who said to her; abstain from circumcision ... for there are families whose blood is loose; while in others it coagulates. (Babylonian Talmud, tractate Yehamot, fol. 64, p. 2 [46])

Armand Quick, in a 1942 review of the history of coagulation, noted that possible cases of a neonatal hemorrhagic disease, distinct from hemophilia, had been reported from time to time as far back as 1682. Quick also postulated that the delay of ritual circumcision by Jews until the eighth day of life may have been based on their empirical observations that neonatal bleeding symptoms have largely waned by that time [47]. 
However, the first definitive description of "the haemorrhagic disease of the newborn" was provided by C.W. Townsend in Boston in 1894. Townsend described a generalized, not local, bleeding disorder, beginning on the second or third day of life. About $0.6 \%$ of newborns were affected with clinical hemorrhage, chiefly into the skin, gastrointestinal tract, and central nervous system. There was a $62 \%$ mortality rate, but if not fatal, the disease was self-limited, with most cases recovering within five days. The sexes were affected equally [48]. The onset of transient bleeding only in the first few days of life, as well as the involvement of girls, clearly differentiated hemorrhagic disease of the newborn from hemophilia.

Lucas and associates performed clotting times, a measure of the entire coagulation mechanism, and showed that during the first four days of life, "there is a definite and fairly consistent prolongation of the coagulation time which favors the so called hemorrhagic condition of the new born" [12]. Whipple in 1912 found that the plasma of a newborn with hemorrhagic disease was deficient in prothrombin; this deficiency was proven definitively by Brinkhous and colleagues in 1937 [49, 50].

Treatment of hemorrhagic disease of the newborn was essentially limited to supportive measures, including local compression when possible [11]. More than half of affected babies died of intracranial hemorrhage or hemorrhagic shock. Lambert in 1908 was able to rapidly reverse the bleeding of an affected baby by a transfusion in which the father's radial artery was anastomosed to the baby's popliteal vein [51]. In 1923, J. B. Sidbury, a practicing pediatrician in North Carolina, treated successfully the hypovolemic shock and bleeding disorder of an affected newborn by giving a blood transfusion through the umbilical vein. Sidbury stated that "human whole blood has acted as a specific in this condition" [52]. In the 1920s, and continuing into the 1940s, the standard treatment of hemorrhagic disease of the newborn, and in some centers the prophylaxis of the condition, was the intramuscular injection of adult blood, often obtained from the father. This was before the discovery of the Rh factor, and led to the
Rh immunization of some girls and erythroblastosis in their offspring [53].

Understanding of the pathogenesis of hemorrhagic disease of the newborn was made possible in 1929, when Dam and associates showed that chicks fed an ether-extracted diet developed a severe bleeding tendency that could be prevented by feeding material extracted and purified from cereals or seeds. They named the correcting factor "Koagulationsvitamin," or vitamin $\mathrm{K}[54,55]$. The nature of the bleeding defect in vitamin K-deficient chicks was soon localized to a deficiency of prothrombin and defined clearly by Brinkhaus and colleagues and Dam and colleagues in normal babies and those with hemorrhagic disease $[50,56]$. Waddell and associates showed that vitamin $\mathrm{K}$ administration could prevent coagulation abnormalities in newborns [57]. Synthesis of vitamin K was accomplished in 1939 [58]. Routine vitamin K prophylaxis $(0.5-1.0 \mathrm{mg}$ ) for all newborns was recommended by the Committee on Nutrition of the American Academy of Pediatrics in 1961, and vitamin K-associated hemorrhagic disease of the newborn has virtually disappeared in the developed world [59]. It should be mentioned, however, that the incidence of hemorrhagic disease of the newborn had decreased markedly in the USA even before vitamin $\mathrm{K}$ prophylaxis became a routine; this decrease was probably a consequence of the declining incidence of breast feeding from the 1930s through the 1960s. The vitamin K content of breast milk is much lower than that of cows' milk, and hemorrhagic disease of the newborn occurs almost exclusively in breast-fed infants who, deliberately or inadvertently, do not receive prophylactic vitamin $\mathrm{K}[60,61]$. The biochemical basis of the action of vitamin $\mathrm{K}$ has been shown to relate to the gamma-carboxylation of glutamic acid residues in the vitamin K-dependent coagulation factors, including prothrombin [62].

\section{Epilog}

This review of the history of neonatal hematology makes clear that study of the blood of the fetus and 
newborn has captured the attention of many pediatricians and hematologists over many years. It is surprising how large their contributions were and that "there is little new under the sun." The sagas of erythroblastosis fetalis and hemorrhagic disease of the newborn illustrate well the progress from clinical recognition and description, to definition of pathogenesis, to empiric and then specific therapy, and finally to prevention.

The majority of work and investigation in neonatal hematology has been performed by pediatric hematologists. However, we are now seeing a generation of hematologists who have been trained in neonatology, who work in newborn special care units, and who have made hematology their clinical and research focus.

As we examine neonatal hematology today, the morphological and quantitative earlier eras of hematology have been succeeded by modern eras of biochemical and genetic investigation of the processes that regulate fetal and neonatal blood and are causes of many of the blood diseases that affect the newborn. Discoveries in these areas will revolutionize neonatal hematology and will make a wonderful story for another historical overview in the twentysecond century, or perhaps even sooner.

\section{REFERENCES}

1 Wintrobe, M. M. Blood, Pure and Eloquent. New York: McGraw-Hill, 1980: 1-31.

2 Leeuwenhoek, M. Microscopical observations concerning blood, milk, bones, the brain, cuticula and spittle. Philos Trans (London) 1674; 9: 121-128.

3 Hewson, W. On the figure and configuration of the red particles of the blood, commonly called the red globules. Philos Trans 1973; 63 (part 2): 303-323.

4 Bizzozero, J. Uber einen neuen Formbestandtheil des Blutes und dessen Rolle bei der Thrombose und der Blutgerinnung. Virch Archiv Pathol Anat Physiol 1882; 90: 261-332.

5 Osler, W. An account of certain organisms occurring in the liquor sanguinis. Proc R Soc Lond 1874; 22: 391-398.

6 Ehrlich, P. Beitrag zur Kenntnis der Amilinfarbungen und ihrer Verwendung in der mikroscopischen Technik. Arch Mikr Anat 1877; 13: 263-277.
7 Wintrobe, M. M. A simple and accurate hematocrit. J Lab Clin Med 1929; 15: 287-289.

8 Wintrobe, M. M. Anemia: classification and treatment on the basis of differences in the average volume and hemoglobin content of the red corpuscles. Arch Intern Med 1934; 54: 256280.

9 Dewees, W. P. A Treatise on the Physical and Medical Treatment of Children. Philadelphia: B. C. Carey \& L. Lea, 1825.

10 Smith, J. L. A Treatise on the Diseases of Infancy and Childhood. Philadelphia: H. C. Lea, 1869.

11 Holt, L. E. The Diseases of Infancy and Childhood. New York: D. Appleton and Co., 1897.

12 Lucas, W. P., Dearing, B. F., Hoobler, H. R., Cox, A., Smythe, F. S. Blood studies in the new-born: morphological, chemical, coagulation, urobilin and bilirubin. Am J Dis Child 1921; 22: 524-558.

13 Lippman, H. S. A morphologic and quantitative study of the blood corpuscles in the new-born period. Am J Dis Child 1924; 27: 473-526.

14 Mattoth, Y., Zaizov, R., Varsano, L. Postnatal changes in some red cell parameters. Acta Paediatr 1971; 60: 317323.

15 Korber, E. Inaugural dissertation, Dorpet, 1866. Cited by Bischoff, H. Untersuchungen uberdie Resistenz des Hamoglobins des menschenblutes mit besonderer beruchsichtigung des Sauglingalters. Z Gesamte Exp Med 1926; 48: 472-489.

16 Singer, K., Chernoff, A. I., Singer, L. Studies on abnormal hemoglobins. 1. Their demonstration in sickle cell anemia and other hematologic disorders by means of alkali denaturation. Blood 1951; 6: 413-428.

17 Apt, L., Downey, W. S. Melena neonatorum: the swallowed blood syndrome; a simple test for the differentiation of adult and fetal hemoglobin in bloody stools. J Pediatr 1955; 47: 612.

18 Kleihauer, E., Braun, H., Betke, K. Demonstration von fetalen Haemoglobin in den Erythrocyten eines Blutaustrichs. Klin Wochenschr 1957; 35: 637-638.

19 Rhinesmith, H. S., Schroeder, W. A., Pauling, L. A quantitative study of hydrolysis of human dinitrophenyl (DNP) globin: the number and kind of polypeptide chains in normal adult human hemoglobin. J Am Chem Soc 1957; 79: 4682-4686.

20 Schroeder, W. A. N-terminal residues of human fetal hemoglobin. JAm Chem Soc 1958; 80: 1521.

21 Bensch, R., Bensch, R. E., Yu, C. I. Reciprocal binding of oxygen and diphosphoglycerate by human hemoglobins. Proc Natl Acad Sci USA 1968; 59: 526-532. 
22 Scott, R. B. Screening for sickle cell in newborn infants. Am J Dis Child 1948; 75: 842-846.

23 Pearson, H. A., O’Brien, R. T., McIntosh, S., Aspnes, G. T., Yang, M. M. Routine screening of umbilical cord blood for sickle cell diseases. J Am Med Assoc 1974; 227: 420422.

24 Benz, E. J., Forget, B. G. The molecular gernetics of the thalassemia syndromes. Prog Hematol 1975; 129: 107-155.

25 Singer, S. T., Styles, L., Bojanski, J., Vichinsky, E. Changing outcome of homozygous alpha-thalassemia: cautious optimism. J Pediatr Hematol Oncol 2000; 22: 539542.

26 Oski, F. A., Naiman, J. L. Hematologic Problems in the Newborn. Philadelphia: W. B. Saunders Co., 1966.

27 Diamond, L. K. Foreword. In Miller, D., Pearson, H. A., McMillan, C. W., eds. Smith's Blood Diseases of Infancy and Childhood. St Louis: C. V. Mosby Co., ix-xiii.

28 Diamond, L. K., Blackfan, F. D., Baty, J. M. Erythroblastosis fetalis, and its association with universal edema of the fetus, icterus gravis neonatorum and anemia of the newborn. J Pediatr 1932; 1: 269-309.

29 Darrow, R. R. Icterus gravis neonatorum: an examination of etiologic considerations. Arch Pathol 1938; 25: 378-417.

30 Landsteiner, K., Weiner, P. An agglutinable factor in human blood recognized by human sera for rhesus blood. Proc Soc Exp Biol Med 1940; 43: 223.

31 Landsteiner, K. Uber Agglutinationserscheiunungen normalen menschlichen Blutes. Wien Klin Wochenschr 1901; 14: 1132-1134.

32 Levine, P., Katzin, E. M., Burnham, L. Isoimmunization in pregnancy: its possible bearing on the etiology of erythroblastosis fetalis. J Am Med Assoc 1941; 116: 825-828.

33 Levine, P., Burnham, L. The role of isoimmunization in the pathogenesis of erythroblastosis fetalis. Am J Obstet Gynecol 1941; 42: 825-827.

34 Hart, A. P. Familial icterus gravis of the newborn and its treatment. Can Med Assoc J 1925; 15: 1008-1019.

35 Wallerstein, H. Erythroblastosis and its treatment. Lancet 1946; 2: 922-924.

36 Weiner, A. S., Wexler, I. B. The use of heparin in performing exchange transfusions in newborn infants. J Lab Clin Med 1946; 31: 1016-1019.

37 Diamond, L. K. Replacement transfusion as a treatment of erythroblastosis fetalis. Pediatrics 1948; 2: 520-524.

38 Allen, F. H., Diamond, L. K. Erythroblastosis Fetalis. Boston, MA: Little, Brown Co., 1957.

39 Weiner, A. S. Diagnosis and treatment of anemia of the newborn caused by occult placental hemorrhage. Am J Obstet Gynecol 1948; 56: 717-722.
40 Chown, B. Anaemia from bleeding of the fetus into the mother's circulation: proof of bleeding. Lancet 1954; 1: 1213 1215.

41 Pearson, H. A., Diamond, L. K. Fetomaterna transfusion. Am J Dis Child 1959; 97: 267-263.

42 Liley, A. W. Liquor amni analysis in the management of the pregnancy complicated by rhesus sensitization. Am J Obstet Gynecol 1961; 82: 1359-1370.

43 Liley, A. W. Intruterine transfusion of foetus in haemolytic disease. Br Med J 1963; 2: 1107-1111.

44 Clarke, C. A. Prevention of Rh hemolytic disease. $\mathrm{Br}$ Med J 1967; 4: 7-12.

45 Freda, V. J., Gorman, J. G., Pollack, W., et al. Prevention of Rh immunization. J Am Med Assoc 1967; 199: 390-394.

46 Garrison, F. H. An Introduction to the History of Medicine, 4th edn. Philadelphia: Saunders, 1929.

47 Quick, A. J. The Hemorrhagic Diseases and the Physiology of Hemostasis. Springfield: Il: C. C. Thomas, 1942.

48 Townsend, C. W. The haemorrhagic disease of the newborn. Arch Pediatr 1894; 11: 559-565.

49 Whipple, G. H. Hemorrhagic disease. Arch Intern Med 1912; 9: 363-399.

50 Brinkhous, K. M., Smith, H. P., Warner, E. D. Plasma protein level in normal infancy and in hemorrhagic disease of the newborn. Am J Med Sci 1937; 193: 475-480.

51 Lambert, S. W. Melena neonatorum with report of a case cured by transfusion. Med Record 1908; 73: 885-887.

52 Sidbury, J. B. Transfusion through the umbilical vein in hemorrhage of the newborn. Am J Dis Child 11923; 25: 290296.

53 Zuelzer, W.W. Pediatric hematology in historical perspective. In Nathan, D. G., Orkin, S. H., ed. Nathan and Oski's Hematology of Infancy and Childhood, 5th edn. Philadelphia: W. B. Saunders, 1998: 3-16.

54 Dam, H., Dyggve, H., Larsen, H., et al. Cholesterolstoffwechsel in Huhneriern und Huhnchen. Biochem Z 1929; 215: 475492.

55 Dam, H., Schonheyder, F., Tage-Hansen, E. Studies on the mode of action of Vitamin K. Biochem J 1935; 215: 12731079.

56 Dam, H., Dyggve, H., Larsen, H., et al. The relationship of Vitamin Kdeficiency to hemorrhagic disease of the newborn. Adv Pediatr 1952; 5: 129-153.

57 Waddell, W. W., Jr, Guerry, D. P., III, Bray, W. E., Kelly, O. R. Possible effects of vitamin $\mathrm{K}$ on prothrombin and clotting time in newly born infants. Proc Soc Exp Biol Med 1937; 40: 432-434.

58 Almquist, H. J., Close, A. A. Synthetic and natural antihemorrhagic compounds. Am J Chem Soc 1939; 61: 2557-2558. 


\section{Cambridge University Press}

0521780705 - Neonatal Hematology

Edited by Pedro A. de Alarcon and Eric J. Werner

Excerpt

More information

59 Committee, on Nutrition of the American Academy of Pediatrics. Vitamin K in the newborn. Pediatrics 1961; 28: 501-507.

60 Dam, H., Glavind, J., Larsen, H., Plum, P. Investigations into the cause of physiological hypoprothrombinemia in newborn children. IV. The vitamin K content of women's milk and cow's milk. Acta Med Scand 1942; 112: 210-216.
61 Sutherland, J. M., Glueck, H. I., Gleser, G. Hemorrhagic disease of the newborn: breast feeding as a necessary factor in the pathogenesis. Am J Dis Child 1967; 113: 524-533.

62 Stenflo, J., Fernlund, P., Egan, W., Raestorff, P. Vitamin Kdependent modifications of glutamic acid residues in prothrombin. Proc Natl Acad Sci USA 1974; 71: 2730-2733. 


\title{
Disorders of the fetomaternal unit
}

\author{
Eric J. Werner, M.D. \\ Eastern Virginia Medical School and Children's Hospital of The King's Daughters, Norfolk, VA, USA
}

\begin{abstract}
In health, the placenta functions marvelously well as the interface between the maternal and fetal circulations, providing nutrition, oxygen, fluid, and electrolytes and removing fetal waste and carbon dioxide. Disorders that disrupt placental physiology, and the presence of pathogens or toxins that can cross the placental barrier, can adversely affect the fetus. This chapter will discuss disorders of the maternalfetal unit that result in hematologic abnormalities in the fetus and/or newborn infant.
\end{abstract}

\section{Hemorrhagic disorders of the fetoplacental unit}

The average blood volume of the fetoplacental circulation is roughly $110 \mathrm{ml} / \mathrm{kg}$ [1], and hence a relatively small amount of blood loss can be a sizable proportion of the fetal blood volume. Placental abnormalities causing fetal blood loss are shown in Table 2.1. Such blood loss can be visible, as with placenta previa, or occult, as with fetomaternal bleeds or twin-twin transfusion syndrome. The clinician must suspect fetal blood loss if the neonate presents with shock and pallor. The placenta and cord should be inspected for pallor, a hematoma, or other anomalies. As discussed below, maternal blood should be studied for the presence of fetal cells.

\section{Abruptio placenta and placenta previa}

While the majority of blood loss with placenta previa or abruptio placenta is maternal, fetal blood loss can also occur [2, 3]. The frequency of neonatal anemia requiring transfusion increases with the severity of maternal bleeding [4]. Vaginal blood can be tested for fetal erythrocytes using the Kleihauer-Betke stain, which identifies cells containing hemoglobin $\mathrm{F}$.

Placental or umbilical-cord damage can cause neonatal anemia. For instance, umbilical cord-blood rupture may occur, especially with traumatic delivery, the presence of velomentous cord insertion, or a multilobed placenta. Surgical laceration of the placenta, as may occur with Cesarian section, may cause significant fetal blood loss.

Infants who have experienced acute hemorrhage during fetal life present with clinical features of acute anemia; pallor, hypovolemia, and hypotension. Unlike patients with hemolytic disorders, these infants do not typically develop hyperbilirubinemia. A hemoglobin measurement immediately following birth often does not reflect accurately the severity of the bleeding. Furthermore, because capillary blood counts are generally higher than central measurements, especially in the acidotic infant, they may underestimate anemia [5]. The management of such infants initially consists of volume replacement, usually with volume expanders such as Ringer's lactate or normal saline. Red-blood-cell transfusion may be indicated for large fetal blood loss.

\section{Fetomaternal bleeds}

Small quantities of fetal erythrocytes pass into the maternal circulation in the majority of pregnancies [6]. In approximately $98 \%$ of pregnancies, less than $2 \mathrm{ml}$ of fetal cells are found in the maternal blood 